\title{
Effect of sheep grazing on a leafy spurge-infested Idaho fescue community
}

\author{
BRET E. OLSON AND ROSEANN T. WALLANDER
}

Authors are associate professor and research associate, Department of Animal and Range Sciences, Montana State University, Bozeman, Mont . 59717.

\begin{abstract}
Leafy spurge (Euphorbia esula L), an aggressive Eurasian forb, is invading native upland ranges dominated by bluebunch wheatgrass (Pseudoroegneria spicata [Pursh] A. Love) and Idaho fescue (Festuca idahoensis Elmer) in the Northern Rocky Mountain Province. Our objective was to determine cumulative effects of 3 summers (1992-1994) of repeated sheep grazing on a leafy spurge infested-Idaho fescue community. Targhee ewes were systematically rotated through paddocks in small pastures. Leafy spurge stem and Idaho fescue and bluebunch wheatgrass plant densities, and frequencies of other species were determined before grazing in 1992, 1993 and 1994, and in 1995, 9 months after grazing ended. Number of viable leafy spurge seeds in seedbanks was determined in 1992 and 1995. Plant heights were measured each year. Density of leafy spurge seedlings was low in grazed and ungrazed areas in 1992 and 1994, whereas density was higher in ungrazed than grazed areas in 1993 and 1995. Grazing did not increase or decrease density of mature leafy spurge stems from 1992 to 1995. Grazing increased density of Idaho fescue but reduced density of bluebunch wheatgrass. Kentucky bluegrass, (Poa pratensis L.), Sandberg bluegrass (Poa sandbergii Vasey), annual bromegrasses (Bromus spp.), and sedge (Carex spp.) frequencies increased in grazed areas. Number of viable leafy spurge seeds in the seedbank was lower in 1995 than in 1992; this reduction was greater in grazed than ungrazed areas. Three years of repeated sheep grazing reduced numbers of leafy spurge seed in the seedbank and seedling densities, but had no effect on density of mature leafy spurge stems. There was minimal effect on the cool season native grasses, possibly because the site was grazed primarily in midsummer when these grasses are dormant. Thus, a long-term commitment to repeated sheep grazing may help to control leafy spurge, although grazed sites should be monitored regularly to ensure that other undesirable species do not increase at the expense of the native plant community.
\end{abstract}

Key Words: weed, density, frequency, seedbank, bluebunch wheatgrass, Euphorbia esula, Festuca idahoensis, Pseudoroegneria spicata

We thank J. Mosley, K. Olson-Rutz, and R. Sheley for reviewing the manuscript. This study was supported by the USDA CSREES and the Montana Agricultural Experiment Station. Published with approval of the Director of the Montana Agricultural Experiment Station, J-5060.

Manuscript accepted: 23 July 1997
Leafy spurge (Euphorbia esula L.), a deep-rooted perennial, was introduced to North America from Russia in the early $1800 \mathrm{~s}$ and has become a noxious weed in the north central United States and southern Canada (Best et al. 1980). It infests over 1.1 million hectares in the United States with severe infestations in Montana, North Dakota, Nebraska, South Dakota, and Wyoming (Lajeunesse et al. 1995). Once leafy spurge is established, it can reduce grass production up to $75 \%$ (Thompson et al. 1990). In North Dakota, leafy spurge reduces grazing capacity for cattle and thereby annual incomes for cattle producers by $\$ 8.6$ million (Leistritz et al. 1992).

Herbicides will not eradicate extensive infestations of leafy spurge, although they can be used to control this noxious weed (Fay 1992). Selected herbicides control top growth, but treatments must be reapplied within 1 to 3 years (Lym and Messersmith 1985). In addition, caution must be exercised when applying most herbicides near irrigation canals, streams, rivers, and wooded areas.

Sheep readily graze leafy spurge (Johnston and Peake 1960, Landgraf et al. 1984, Olson et al. 1996). Although sheep will not eradicate leafy spurge, sheep may minimize its spread and reduce infestations over time. Sheep may be the only cost-effective method of controlling leafy spurge (Fay 1991). However, sheep will ingest leafy spurge seed and deposit viable seed in their manure, thus they have to be managed accordingly (Lacey et al. 1992, Olson et al. 1997a). Besides controlling leafy spurge, sheep, unlike herbicides, provide a source of income on leafy spurge-infested cattle ranches (Williams et al. 1996).

Historically, leafy spurge infested abandoned crop- and haylands, partly because leafy spurge seed often contaminated seed of common hay species such as smooth brome (Bromus inermis Leys) and alfalfa (Medicago sativa L., reviewed in Dunn 1985). Many of the associated grasses on these lands are introduced, thizomatous (sodformers) species such as smooth brome and Kentucky bluegrass (Poa pratensis L.). In Montana, leafy spurge has not spread as rapidly onto native rangelands dominated by bunchgrasses. This could reflect that bunchgrasses are more competitive with leafy spurge than rhizomatous grasses, that herbivores prefer leafy spurge to native bunchgrasses, or that leafy spurge simply has not been transported to these upland sites. Our objective was to assess cumulative effects of 3 summers of repeated grazing by sheep on a leafy spurge infested-Idaho fescue plant community dominated by native bunchgrasses. 


\section{Methods and Materials}

Our study site was located in Gallatin County in southwestern Montana ( $\left.111^{\circ} 33^{\prime} \mathrm{W} 45^{\circ} 40^{\prime} \mathrm{N}\right), 1,480 \mathrm{~m}$ above sea level on northeast-facing terraces above the Madison River. The site is about $50 \mathrm{~km}$ west of Bozeman, Mont., which has the nearest long-term recording weather station. Soils are classified as loamy skeletal mixed Aridic Calciborolls. The rangeland cover type is Idaho fescue (Festuca idahoensis)-bluebunch wheatgrass (Agropyron spicatum; Shiflet 1994). Until the early 1990s, the area was most recently grazed by yearling cattle during summer.

\section{Grazing treatments}

Each year, 2 groups of yearling T'arghee ewes were used for a concurrent study on the role of experience in sheep grazing leafy spurge (Olson et al. 1996). One group of yearlings (naive) had no previous exposure to leafy spurge as lambs on the summer foothill rangeland with their ewes, whereas the second group (experienced) grazed a leafy spurge-infested (25\% canopy coverage) foothill rangeland as lambs with their mothers.

Our 5.1 ha site was subdivided into three 1.7 -ha pastures (blocks). Each block was further divided into 2 lanes, one for an experienced group, and one for a naive group of yearlings. Each lane was further subdivided so yearlings could be rotated among 3 small paddocks. In 1992, 5 yearlings grazed each lane, whereas 4 yearlings grazed each lane in 1993 and 1994. Grazing began in late May or early June, depending on the year. Yearlings were rotated from Paddock 1 to Paddock 2 to Paddock 3, and then back to Paddock 2 (Fig.1). Paddock 2 was approximately twice the size of Paddocks 1 and 3. This cycle was repeated each year. Thus, plants in Paddocks 1 and 3 had an equal probability of being grazed at least twice each summer, whereas those in Paddock 2 could have been grazed at least 3 times each summer. The stocking rate was 2.9 AUMs ha $\mathrm{An}^{-1}$ in 1992, 3.1 $\mathrm{AUMs} \mathrm{ha}^{-1}$ in 1993, and 2.4 AUMs ha ${ }^{-1}$ in 1994.

Canopy coverage of leafy spurge varied from $35-65 \%$ across the site, other forbs comprised $1-10 \%$, and cool-season perennial grasses comprised the remainder of the plant community in each paddock. The distribution of leafy spurge was nonuniform within each paddock.

\section{Plant Community Response}

Before sheep grazing began in May 1992, we randomly located 2 exclosures in each paddock. Ten plots $\left(0.25 \mathrm{~m}^{2}\right)$ were estab-

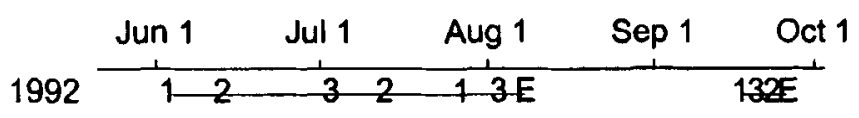

1993

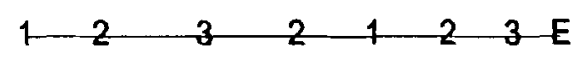

1994

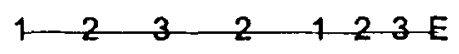

Fig. 1. Grazing rotation of the yearlings among Paddocks 1, 2, and 3. The schedule varied within years and from year to year based on forage availability. On the time lines, " $E$ " indicates when grazing ended for that particular sequence. lished at $1 \mathrm{~m}$ intervals along paired, $10 \mathrm{~m}$ permanent transects inside and outside each exclosure. Densities of leafy spurge seedlings and mature stems, and Idaho fescue and bluebunch wheatgrass plants were determined. Frequency of dandelion (Taraxacum officinale Weber), Kentucky bluegrass, Sandberg bluegrass (Poa sandbergii Vasey), annual bromegrasses (predominately cheatgrass Bromus tectorum L.), western wheatgrass (Pascopyron smithii Rydb. Love), sedge (Carex) spp. and blue grama (Bouteloua gracilis (H.B.K.) Lag.) was recorded. Density and frequency were remeasured before grazing in 1993 and 1994 and in May 1995, the year following the last grazing. Heights of leafy spurge stems, Idaho fescue leaves, and bluebunch wheatgrass leaves were measured midsummer each year. Utilization (percent canopy removed) of marked stems (leafy spurge) and plants (Idaho fescue, bluebunch wheatgrass) was estimated 3 times in the summers of 1993 and 1994 (Table 1).

Table 1. Utilization (\% canopy removed) of leafy spurge, Idaho fescue, and bluebunch wheatgrass during the summers of 1993 and 1994. Percent canopy removed was not measured during the summer of 1992.

\begin{tabular}{|c|c|c|c|c|c|c|}
\hline \multirow{2}{*}{$\begin{array}{l}\text { Year } \\
\text { Grazing period }\end{array}$} & \multicolumn{3}{|c|}{1993} & \multicolumn{3}{|c|}{1994} \\
\hline & 1 & 2 & 3 & 1 & 2 & 3 \\
\hline Species & -1 & - & can & remo & $1-$ & -- \\
\hline Leafy spurge & 50 & 49 & 43 & 37 & 82 & 78 \\
\hline Idaho fescue & 34 & 39 & 40 & 26 & 43 & 47 \\
\hline Bluebunch wheatgrass & 28 & 45 & 26 & 26 & 29 & 26 \\
\hline
\end{tabular}

Before seed set in 1992, 10 soil cores were extracted from the area between grazed and ungrazed transects associated with each exclosure $(20$ cores per paddock $\times 3$ paddocks per lane $\times 2$ lanes per block $=120$ cores per block) to determine initial seedbanks of leafy spurge. These soil cores were removed with a tulip bulb corer (5.7 cm dia.) placed $7.5 \mathrm{~cm}$ deep in the soil, which extracted $191 \mathrm{~cm}^{3}$ of soil. These samples,were air-dried and placed in cold storage $\left(4^{\circ} \mathrm{C}\right)$. In 1995,10 soil cores were extracted along grazed and ungrazed transects (120 cores along grazed transects and 120 cores along ungrazed transects per block), and air-dried. In 1995, seedbank samples from 1992 and 1995 were washed through sieves to remove fine material. Remaining material was dried at $37^{\circ} \mathrm{C}$ for 48 hours and examined for leafy spurge seeds. Leafy spurge seeds recovered from each transect were combined and then tested for percent germination. Up to 100 seeds were maintained in groups of 20 seeds on moist blotter paper in petri dishes. Petri dishes were placed in a greenhouse with $21^{\circ} \mathrm{C}$ daytime- $13^{\circ} \mathrm{C}$ nighttime temperatures, and protected from direct sunlight. Germinating seeds (radicle length $>10 \mathrm{~mm}$ ) were counted and removed every 2 days for 20 days. Petri dishes were placed into cold storage for 4 weeks. Petri dishes were returned to the greenhouse, germinating seeds were counted and removed every 2 days for 14 days. Seeds that did not germinate were tested for viability with tetrazolium (Grabe 1970). In the results, number of viable seed includes those that tested positive with tetrazolium, and those that germinated in the petri dishes.

\section{Statistical Analyses}

Densities, frequencies, and pregrazing heights in 1992 to 1994 , and early summer 1995, 9 months after the last grazing, were analyzed with univariate repeated measures analysis of variance 
in a randomized-complete-block design ( $\mathrm{n}=3$ blocks; GLM, SAS 1988). Between subject factors were paddock $(1,2,3)$, previous experience of sheep (naive, experienced), grazing (yes, no), and their interactions. The within subject effect was year. The 4 way interaction (year by paddock by experience by grazing) was never significant. At times one or more of the 3 way interactions was significant but it always reflected a difference in magnitude not response, so only grazing by year is emphasized in the results. Percent change in number of viable seed in seedbanks from 1992 to 1995 were analyzed with analysis of variance using the same main effects and interactions. Percent data were arcsine square root transformed, but arithmetic means are reported. Block was included in all models as a random effect (Sokal and Rohlf 1995). Each plant species was analyzed separately. Residuals from analyses of variance were normally distributed.

\section{Results}

\section{Plant Community Response}

Leafy spurge seedling density was uniformly low in grazed and ungrazed areas in 1992 and 1994 (Fig. 2), while density was higher in ungrazed than grazed areas in 1993 and 1995 (grazing by year, $\mathrm{P}<0.0001$ ). Grazing did not affect density of mature leafy spurge stems from 1992 to 1995 (grazing by year, $\mathbf{P}=$ 0.87 ), but stem density was greater in grazed and ungrazed areas in 1994 than the other years (year, $P<0.0001$ ).

Grazing increased the density of Idaho fescue from 1992 to 1995 (Fig. 3; grazing by year, $\mathrm{P}<0.0002$ ). Grazing tended to reduce the density of bluebunch wheatgrass (grazing by year, $\mathrm{P}<0.08$ ), partly reflecting that initial plant densities were greater along grazed than ungrazed transects. Grazing increased frequency of dandelion $(P<0.0001)$,

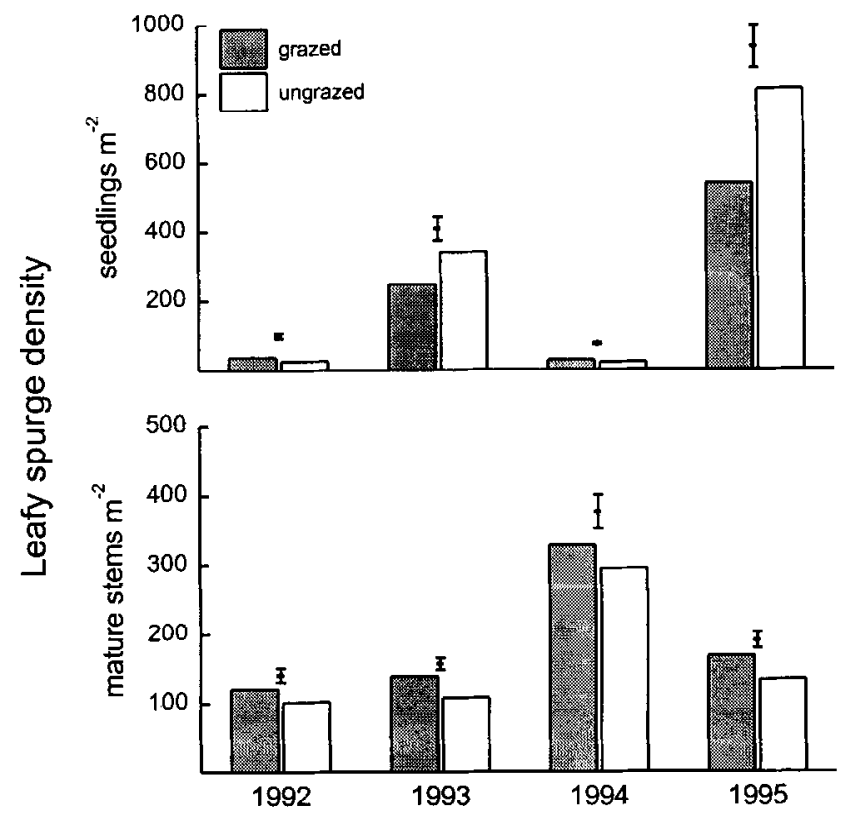

Fig. 2. Densities of leafy spurge seedlings and mature stems from 1992 to 1995 in grazed and ungrazed areas. Densities in 1992 were determined before the sheep first grazed the pastures. Densities in 1995 were those determined after 3 years of sheep grazing. Error bars represent \pm 1 S.E. of least square means.
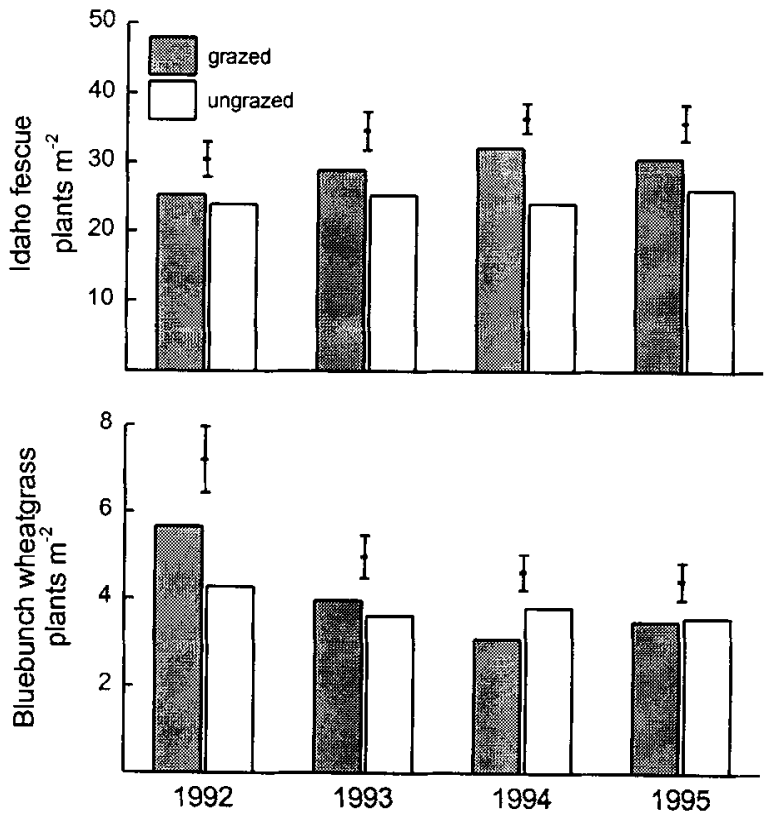

Fig. 3. Density of Idaho fescue and bluebunch wheatgrass plants from 1992 to 1995 in grazed and ungrazed areas. Error bars represent \pm 1 S.E. of least square means.

Kentucky bluegrass $(\mathrm{P}<0.03)$, Sandberg bluegrass $(\mathrm{P}<0.001)$, annual bromegrasses $(\mathrm{P}<0.02)$, and sedges $(\mathrm{P}<0.005)$ from 1992 to 1995 (Fig. 4; grazing by year). Grazing had no effect on western wheatgrass $(P=0.19)$ or blue grama $(P=0.15)$.

\section{Plant Heights}

Grazing reduced heights of leafy spurge stems and Idaho fescue plants from 1992 to 1995, whereas they each increased in height without grazing (Fig. 5; grazing by year, both species $\mathrm{P}<0.0001$ ). Heights of bluebunch wheatgrass increased from 1992 to 1995 with and without grazing, although the increase was greater on ungrazed plants (grazing by year, $\mathrm{P}<0.015$ ).

\section{Seedbanks}

Number of viable seeds in the seedbank was lower in 1995 than in 1992 (Table 2). The reduction was greater in grazed (65\%) than ungrazed areas $(45 \% ; \mathrm{P}<0.009)$. Sixty-three percent of the leafy spurge seed collected from seedbanks sampled in 1992 was viable. Forty-four percent of leafy spurge seed collected from seedbanks sampled in 1995 was viable. Of the nonviable seed, most were empty.

Table 2. Number of viable leafy spurge seed $\left(\mathrm{m}^{-2}\right.$; mean and standard error) and percent change of number of viable leafy spurge seed in the soil seedbank from 1992" to 1995 along grazed and ungrazed transects.

\begin{tabular}{llrrc}
\hline & & $\widetilde{\mathrm{x}}$ & $\mathrm{SE}$ & \% change $^{\mathrm{b}}$ \\
\hline 1992 & baseline & 2,001 & 436 & NA \\
1995 & grazed & 685 & 98 & -65 \\
& ungrazed & 1,103 & 122 & -45 \\
\hline
\end{tabular}

aseedbank soil cores were collected between grazed and ungrazed transects in 1992 to avoid areas that would be sampled in 1995 .

\%change $-\left(\right.$ seeds $\mathrm{m}^{-2}$ in 1992-seeds $\mathrm{m}^{-2}$ in 1995) seeds $\mathrm{m}^{-2}$ in 1992) $\times 100$ 

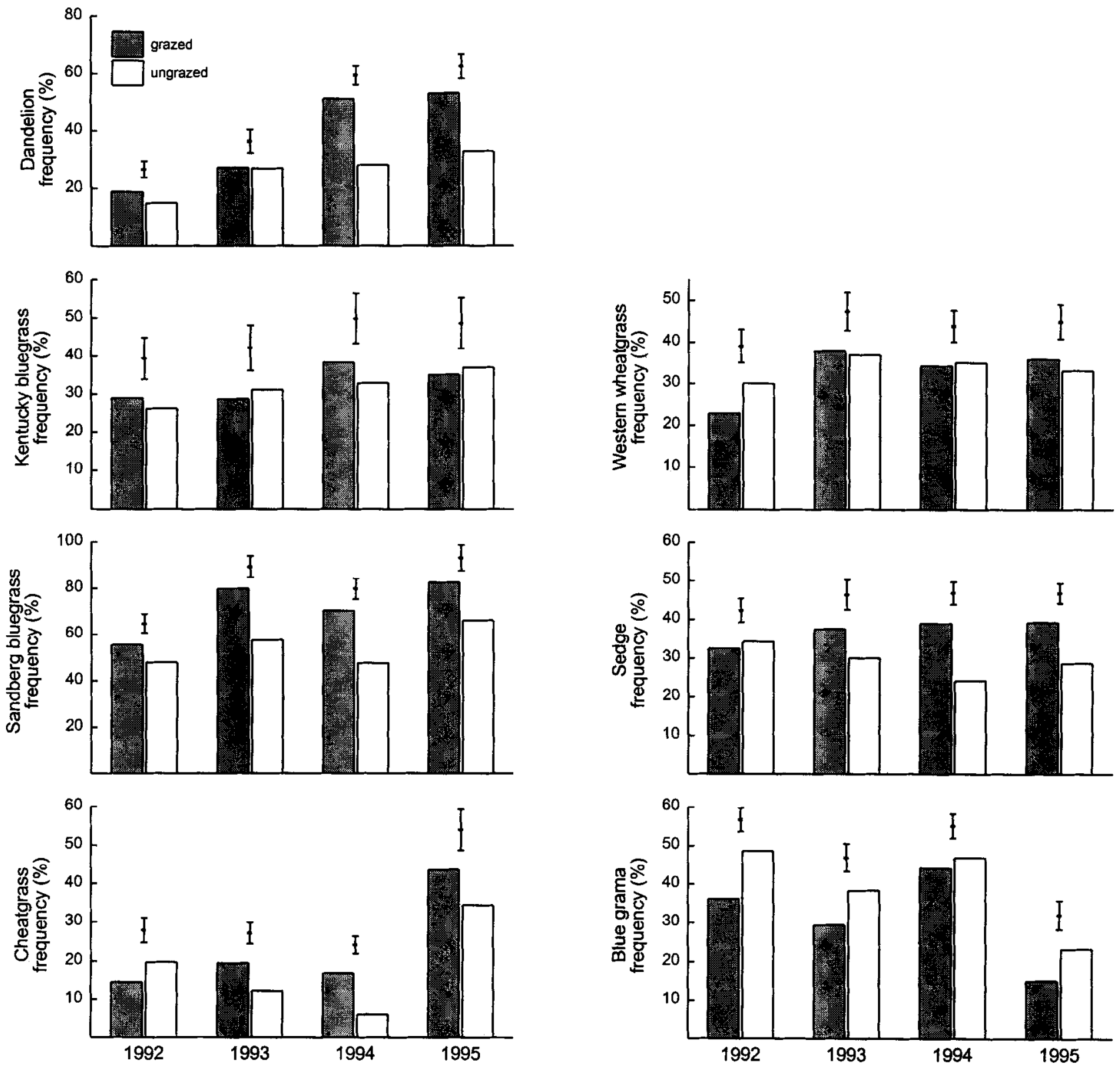

Fig. 4. Frequency of dandelion, Kentucky bluegrass, Sandberg bluegrass, cheatgrass, western wheatgrass, sedge, and blue grama from 1992 to 1995 in grazed and ungrazed areas. Error bars represent \pm 1 S.E. of least square means.

\section{Discussion}

Sheep tend to prefer leafy spurge more than some perennial grasses, e.g.crested wheatgrass, but less than others, e.g., Kentucky bluegrass (Johnston and Peake 1960), possibly because of differences in plant phenology, palatability, or their lack of experience with leafy spurge. Preferred grasses will be at a competitive disadvantage to leafy spurge (Briske 1990), especially when grazed at certain developmental stages (Olson and Richards 1988). If sheep grazing negatively affects leafy spurge and associated native grasses, undesirable species such as cheatgrass and spotted knapweed (Centaurea maculosa Lam.) could invade the site

\section{Plant Community Response}

Leafy spurge spreads by seeds and lateral roots. Three years of repeated sheep grazing reduced seed numbers in the seedbank compared with ungrazed areas, probably because sheep consume seed capsules and thereby reduce seed rain onto the soil surface (Olson et al. 1997a). In Saskatchewan, continuous summer-long sheep grazing reduced the size of a leafy spurge seedbank from more than 3,500 seeds $\mathrm{m}^{-2}$ to 15 seeds $\mathrm{m}^{-2}$ after 8 years (Bowes and Thomas 1978). Seedbanks and perennial shoot densities should be reduced concurrently to control any competitive species over the long term (Bowes and Thomas 1978, Marlette and Anderson 1986).

Number of viable seeds in seedbanks was lower in 1995 than in 1992 in grazed and ungrazed areas. The number of seeds in seedbanks varies widely from year to year (e.g. Coffin and Lauenroth 1989) because seed production in previous years and weather of 
Table 3. Thirty-year averages (1961-1990) and 1992-1995 mean temperatures and total precipitation for April through August, Bozeman, Mont.

\begin{tabular}{|c|c|c|c|c|c|c|c|c|c|c|}
\hline \multirow[b]{2}{*}{ Month } & \multicolumn{6}{|c|}{ Temperature } & \multicolumn{4}{|c|}{ Precipitation } \\
\hline & $\begin{array}{l}\text { 30-year } \\
\text { average }\end{array}$ & 1992 & 1993 & 1994 & 1995 & $\begin{array}{l}30 \text {-year } \\
\text { average }\end{array}$ & 1992 & 1993 & 1994 & 1995 \\
\hline & $\ldots-\ldots$ & $\ldots$ & $-\left({ }^{\circ} \mathrm{C}\right)$ & $\ldots$ & $\cdots$ & $\ldots \ldots$ & $\ldots$ & am) - - & $\ldots$ & $\ldots$ \\
\hline Apr & 5.9 & 8.6 & 6.4 & 7.8 & 5.6 & 48 & 80 & 81 & 49 & 70 \\
\hline May & 10.8 & 13.5 & 13.5 & 13.5 & 9.9 & 81 & 71 & 84 & 37 & 68 \\
\hline Jun & 15.6 & 16.7 & 14.1 & 16.1 & 15.2 & 73 & 139 & 107 & 89 & 47 \\
\hline Jul & 19.6 & 16.9 & 14.8 & 19.7 & 19.5 & 34 & 44 & 126 & 69 & 71 \\
\hline Aug & 18.8 & 17.8 & 16.0 & 20.7 & 19.6 & 38 & 23 & 73 & 15 & 67 \\
\hline
\end{tabular}

the current year can vary widely. For example, seed production was low during the drier summer of 1994 (Olson et al. 1997a) which could explain reduced seed numbers in the seedbank in 1995.

Weather may have had a major effect on the density of leafy spurge seedlings. Seedling densities were uniformly low in grazed and ungrazed areas (less than 36 seedlings $\mathrm{m}^{-2}$ ) in 1992 and 1994. Mean temperatures in April and May of 1992 and 1994 (Table 3) were considerably higher than the long term average, which may have hindered seed germination and seedling survival. In contrast, cool to normal mean temperatures combined with above average precipitation in April 1993 and 1995 may have promoted seed germination and seedling survival. Seedling densities were high during the summers of 1993 and 1995, averaging over 800 seedlings $\mathrm{m}^{-2}$ in ungrazed and 534 seedlings $\mathrm{m}^{-2}$ in grazed areas. In dense leafy spurge, stands, seedling densities can reach 1,073 seedlings $\mathrm{m}^{-2}$ (Selleck et al. 1962). The low seed production in 1994 and high seedling densities in 1995 could explain the relatively low number of seeds in the seedbank in 1995. We did not monitor percent survival of marked leafy spurge seedlings, however, many second year plants were observed in 1994. Typically, survival of leafy spurge seedlings is low (Selleck et al. 1962, Bowes and Thomas 1978, Best et al. 1980), but the few seedlings that become established can become an epicenter of a new infestation on disturbed sites (Selleck et al. 1962).

In 1993 and 1995, the lower density of leafy spurge seedlings in grazed than in ungrazed areas could reflect one or more factors. First, sheep consume seed capsules of leafy spurge (Bowes and Thomas 1978, Olson et al. 1997a), and seed viability is reduced after passing through the gastrointestinal tract (Lacey et al. 1992, Olson et al. 1997a). This reduces the number of viable seeds contributed to the seedbank. Second, repeated sheep grazing may have reduced the ability of the shoots to produce flower heads. Few flower heads are produced when leafy spurge is clipped repeatedly at moderate and heavy levels of defoliation (Al-Rowaily 1996). Third, conditions for germination may be less favorable on areas grazed regularly by sheep because of greater fluctuations in soil temperature and water content, and high wind speeds associated with grazing and trampling. On the other hand, conditions could be more favorable for germination because leafy spurge seedlings establish more readily on mineral soil than in undisturbed vegetation (Best et al. 1980). Apparently, negative effects of greater fluctuations in microclimate on seedling establishment offset any positive effects associated with greater amounts of mineral soil caused by grazing.

Grazing did not increase or decrease the density of mature leafy spurge stems from 1992 to 1995 . Leafy spurge has a deep, extensive root system (Bakke 1936), which is relatively impervious to any disturbance, including herbivory, herbicides, mowing, or fire. Often, such aboveground disturbances will actually increase stem densities by removing apical dominance and stimulating growth of root buds (Selleck et al.1962). However, others have found that continuous sheep grazing will reduce stem densities of leafy spurge. In Saskatchewan, summerlong continuous sheep grazing had no effect on stem densities for the first 3 years, after which they declined dramatically (Bowes and Thomas 1978).

Grazing increased the density of Idaho fescue plants from 1992 to 1995 . Increases in density could reflect actual increases in the number of new plants or fragmentation of existing plants (Briske 1990). We did not monitor changes in plant basal area during the 4 years of the study. If increased density was associated with
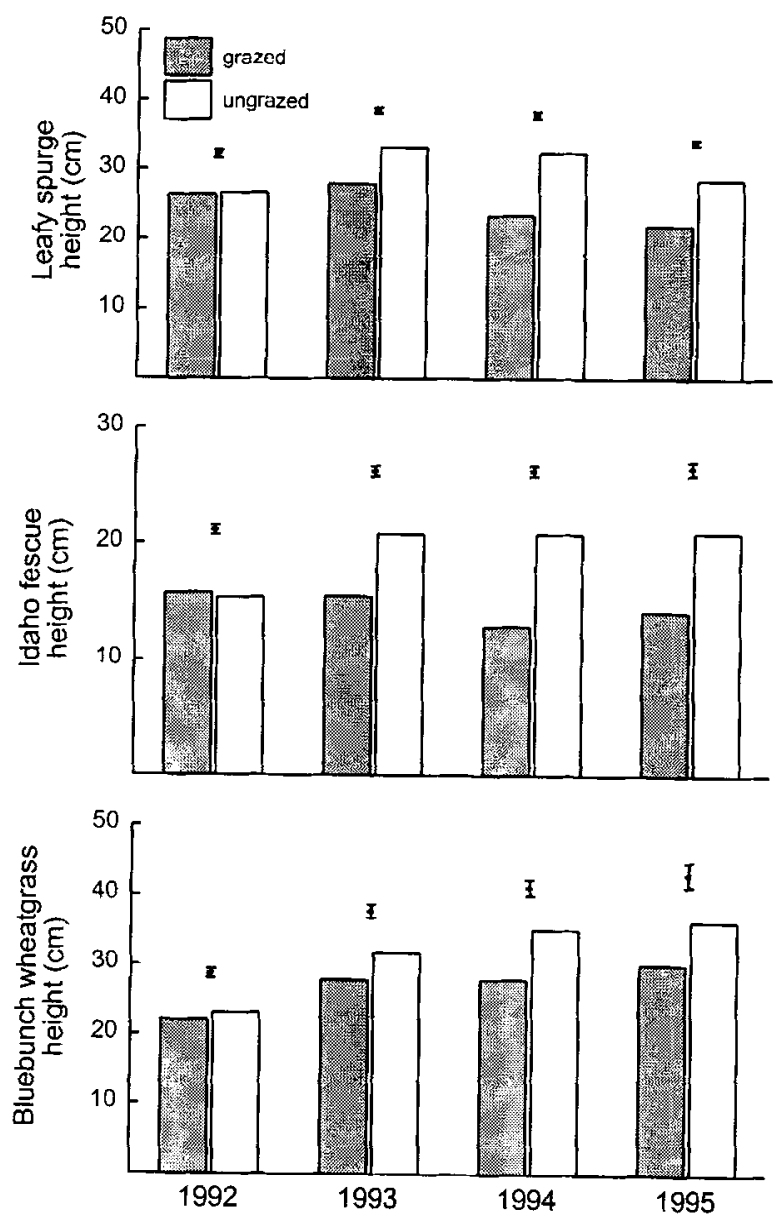

Fig. 5. Heights of leafy spurge, Idaho fescue, and bluebunch wheatgrass in grazed and ungrazed areas before grazing in 1992 to 1994 , and in early summer 1995, 9 months after the last grazing event. Error bars represent \pm 1 S.E. of least square means. 
reduced basal area on a per plant basis, the competitive ability of individual grasses may be compromised.

Grazing increased frequency of dandelion, Kentucky bluegrass, Sandberg bluegrass, annual bromegrasses, and sedges from 1992 to 1995. All of these species increase with cattle grazing, and have different strategies for tolerating defoliation (USDA Forest Service 1937). Dandelion is a prolific seed producer, and its flower stalks become more prostrate with defoliation or mowing. Kentucky bluegrass is also an abundant seed producer, a sodformer, and highly resistant to defoliation. Sandberg bluegrass has a deep, penetrating mass of coarse roots which allows it to withstand trampling well. Threadleaved-sedge (Carex filifolia Nutt.; USDA Forest Service 1937) is also resistant to defoliation. Cheatgrass, the most common annual bromegrass at this site, is a prolific seed producer and is only palatable for a relatively short time. Because of the potential of these less desirable species to increase, an entire plant community grazed repeatedly by sheep should be monitored, not just leafy spurge and the dominant bunchgrasses.

\section{Plant Heights}

Grazing can also affect plants by reducing plant heights. Stem or leaf heights have often been used as an indicator of plant vigor (Mueggler 1975, Cook and Stubbendieck 1986). For example, 1 year after grazing, stem heights of crested wheatgrass tillers are lower on plants grazed during internode elongation than those grazed before internode elongation (Olson and Richards 1988). In this study, heights of leafy spurge stems and Idaho fescue leaves along grazed transects were lower than along ungrazed transects from 1992 to 1995. Repeated sheep grazing reduces heights of Idaho fescue but does not reduce heights of spotted knapweed in a spotted knapweed-infested, Idaho fescue community (Olson et al. 1997b).

Heights of bluebunch wheatgrass increased from 1992 to 1995 with and without grazing, although the increase was greater on ungrazed plants. The increases in heights of bluebunch wheatgrass may reflect that sheep grazed bluebunch wheatgrass less than Idaho fescue or leafy spurge (Table 1), that most of the grazing occurred when bluebunch wheatgrass was dormant, or both. Therefore, bluebunch wheatgrass may be able to maintain a competitive advantage when sheep are the primary grazers in mid-summer.

\section{Conclusions}

Three years of repeated sheep grazing of leafy spurge significantly reduced seeds in the seedbank and seedling densities, potentially minimizing the rate of spread by seeds. But repeated sheep grazing had no effect, positive or negative, on mature stem densities which has greater implications for affecting native vegetation over the long-term. Although stem densities were not reduced, stem heights were reduced indicating that the competitive ability of leafy spurge may have been reduced in the shortterm. Response of the associated plants was mixed. Plant species that commonly increase with grazing such as dandelion, Kentucky bluegrass, and annual bromegrasses, increased. Densities of Idaho fescue and especially bluebunch wheatgrass were not significantly affected by the repeated grazing, possibly because most of the grazing occurred while these grasses were dormant. However, shorter leaves on Idaho fescue may indicate reduced vigor, similar to the shorter stems observed on leafy spurge. Our results indicate that sheep grazing was having a negative effect on the recruitment stages of leafy spurge: leafy spurge seed in the seedbank and seedling densities. Thus, a longterm commitment to repeated sheep grazing may help to control leafy spurge. However, grazed sites should be monitored regularly to ensure that other undesirable species do not increase at the expense of the native plant community.

\section{Literature Cited}

Al-Rowaily, S.L. 1996. Influence of clipping, sheep and goat grazing, and competition on growth and reproduction of leafy spurge on a rangeland site in southeastern Montana.PhD.Diss, Utah State Univ, Logan, Ut. 133 pp

Bakke, A.L. 1936. Leafy spurge, Euphorbia esula L.Iowa Agr .Exp.Sta. Res. Bull 198:209-246.

Best, K.F., G.G. Bowes, A.G. Thomas, and M.G. Maw.1980. The biology of Canadian weeds.39. Euphorbia esula L.Can.J.Plant Sci. 60:651-663.

Bowes, G.G. and A.G. Thomas. 1978. Longevity of leafy spurge seeds in the soil following various control programs. J.Range Manage. 31:137-140.

Briske, D.D. 1990. Developmental morphology and physiology of grasses, p.85-108. In: R.K.Heitschmidt and J.W.Stuth (eds.), Grazing management: an ecological perspective. Timber Press, Portland, Ore.

Coffin, D.P. and W.K. Lauenroth.1989. Spatial and temporal variation in the seed bank of a semiarid grassland.Amer. J. Bot. 76:53-58.

Cook, C.W. and J. Stubbendieck.1986. Range research: basic problems and techniques. Soc.Range Manage. Denver, Colo.

Dunn, P.H. 1985. Origins of leafy spurge in North America. p. 7-13. In: A.K.Watson (ed.), Leafy spurge monograph series no.3, Weed Sci. Soc. Amer. Champaign, IIl.

Fay, P.K. 1991. Controlling leafy spurge with grazing animals. p. 193-199. In L.F.James, J.O.Evans, M.H.Ralphs, and R.D.Child (eds.), Noxious range weeds. Westview Press, Boulder, Colo.

Fay, P.K. 1992. The role of herbicides in weed management.Western Wildlands, Summer Issue.

Grabe, D.F.ed. 1970. Tetrazolium handbook.Assoc.Official Seed Analysts.62 p.

Johnston, A. and R.W. Peake. 1960. Effect of selective grazing by sheep on the control of leafy spurge (Euphorbia esula L.). J.Range Manage.13:192-195.

Lacey, J.R., R. Wallander, and K. Olson-Rutz. 1992. Recovery, germinability, and viability of leafy spurge (Euphorbia esula) seeds ingested by sheep and goats. Weed Tech. 6:599-602.

Lajeunesse, S., R. Sheley, R. Lym, D. Cooksey, C. Duncan, J. Lacey, N. Rees, and $M$. Ferrell. 1995. Leafy spurge: biulugy, ecology and management. Mont. State Univ. Ext. Ser. EB-134.

Landgraf, B.K., P.K. Fay, and K.M. Havstad. 1984. Utilization of leafy spurge (Euphorbia esula) by sheep.Weed Sci.32:348-352.

Leistritz, L.F., A. Bangsund, N.M. Wallace, and J.A. Leiteh. 1992. Economic impact of leafy spurge on grazingland and wildland in North Dakota. N. Dakota State Univ. AE 92005.14 p.

Lym, R.G. and C.G. Messersmith.1985. Leafy spurge control and improved forage production with herbicides. J.Range Manage. 38:386-391.

Marlette, G.M. and J.E. Anderson.1986. Seed banks and propagule dispersal in crested wheatgrass stands. J. Appl. Ecol. 23:161-175.

Mueggler, W.F. 1975. Rate and pattern of vigor recovery in Idaho fescue and bluebunch wheatgrass. J. Range Manage 28:198-204.

Olson, B.E. and J.H. Richards.1988. Annual replacement of the tillers of Agropyron desertorum following grazing. Decologia 76:1-6.

Olson, B.E., R.T. Wallander, and R.W. Kott.1997a. Recovery of leafy spurge seed from sheep. J. Range Manage. 50:10-15.

Olson, B.E., R.T. Wallander, and J.R. Lacey. 1997b. Effects of sheep grazing on a spotted knapweed-infested Idaho fescue community. J. Range Manage. 50:386-390.

Olson, B.E., R.T. Wallander, V.M.Thomas, and R.W. Kott.1996. Effect of previous experience on sheep grazing leafy spurge. Appl. Anim. Behav. Sci. 50:161-176.

SAS. 1988. Statistical analysis system.SAS Institute Inc. Raleigh, N.C.

Selleck, G.W., R.T.Coupland, and C. Frankton. 1962. Leafy spurge in Saskatchewan. Ecol. Mono. 32:1-29.

Shiflet, T.N.1994. Rangeland cover types. Soc. Range Manage. Denver, Colo.

Sokal, R.R. and F.J. Rohlf.1995. Biometry, 3rd Edition. W.H. Freeman and Co. New York.

Thompson, F., F.L. Leistritz, and J.A.Leitch.1990. Econornic impact of leafy spurge infestations in North Dakota. North Dakota State Univ. Agr. Econ. Rep. Nu.257.

USDA Forest Service.1937. Range plant handbook. Dover Publications, Inc., New York.

Wilkiams, K.E., J.R. Lacey, and B.E.Olson. 1996. Economic feasibility of grazing sheep on leafy spurge-infested rangelands in Montana. J. Range Manage. 49:372-374. 